\title{
Validation of an Inductively Coupled Plasma-Optical Emission Spectrometry Method for the Determination of Major Elements in Farmed Rainbow Trout (Oncorhynchus mykiss) ${ }^{1}$
}

\author{
S. Velasco ${ }^{a, *}$, L. T. Ortiz ${ }^{a}$, M. L. Rodríguez ${ }^{a}$, A. Reboléa $^{a}$, J. Treviño $^{a}$, T. Benito ${ }^{b}$, \\ I. Gómez-Pinilla ${ }^{b}$, and S. López-Andrés ${ }^{b, c}$ \\ ${ }^{a}$ Departamento de Producción Animal, Facultad de Veterinaria, Universidad Complutense de Madrid, Madrid 28040, Spain \\ ${ }^{b}$ CAI de Técnicas Geológicas, Universidad Complutense de Madrid, Madrid 28040, Spain \\ ${ }^{c}$ Departamento de Cristalografía y Mineralogía, Facultad de Ciencias Geológicas, Universidad Complutense de Madrid, \\ Madrid 28040, Spain \\ *e-mail: suvelasc@ucm.es \\ Received June 29, 2016; in final form, January 25, 2017
}

\begin{abstract}
An inductively coupled plasma-optical emission spectrometry method was optimized and validated for the determination of major elements $(\mathrm{Ca}, \mathrm{K}, \mathrm{Mg}, \mathrm{Na}$ and $\mathrm{P}$ ) in cultivated freshwater fish (rainbow trout Oncorhynchus mykiss). The method was validated by analysis of a Certified Reference Material, consisting in a frozen tissue homogenate from lake trout (Salvelinus namaycush namaycush). The linearity of this method was very good, as evidenced by the coefficients of correlation $(r)$ for calibration graphs that were higher than 0.9999 in all cases and by linearity test (response factor $<5 \%$ and relative calibration graph slope $<2 \%$ ). Accuracy, expressed as relative recovery $(\%)$ in comparison with certified concentration ranged from 100 to $109 \%$, and precision, expressed as residual standard deviation (\%) ranged from 1.2 to $6.5 \%$ (repeatability) and from 1.0 to $9.6 \%$ (reproducibility). The limit of quantification ranged from $4 \mathrm{ng} / \mathrm{mL}(\mathrm{Ca}$ and $\mathrm{Mg})$ to $203 \mathrm{ng} / \mathrm{mL}$ (P). The optimized method was applied to major element determination in skin and muscle samples from rainbow trout fillets.
\end{abstract}

Keywords: inductively coupled plasma-optical emission spectrometry, microwave digestion, major element determination, method and validation, fish, rainbow trout, food composition, Oncorhynchus mykiss

DOI: $10.1134 / \mathrm{S} 106193481709012 \mathrm{X}$

During the past few decades, the consumption of fish has increased in many European countries, particularly in Spain. In this country, fish consumption has been traditionally based on marine species, but the increased demand and consequently increased prices for fresh marine species, have gradually expanded the production and consumption of farmed fish. Published data [1] show that the production of cultivated fish, crustacean and molluscs was 48900 metric tons in 2012, rainbow trout (Oncorhynchus mykiss) being the most widely cultivated fish species (16620 metric tons). From a nutritional point of view, both marine and fresh water fish are a good source of high biological value protein, major and trace essential minerals, vitamins as well as physiologically important fatty acids. Thus, fish product consumption can have beneficial effects for human health [2-5].

Marine and fresh water fish may absorb minerals from diet and also from surrounding water [6]. Therefore, available information on the mineral content in

\footnotetext{
${ }^{1}$ The article is published in the original.
}

fish is important not only from a nutritional standpoint, but also from a toxicological protection view. A number of factors including age, size, food, sex and environmental conditions are believed to be responsible for the wide variations observed in the reported values of mineral composition in the same fish species [7, 8]. Moreover, it should be also taken into account that both the sample preparation and the analytical procedure may influence the accuracy and precision of compositional determinations.

Analytical techniques to quantify mineral elements in fish samples mainly included atomic absorption spectrometry, inductively coupled plasma-optical emission spectrometry (ICP-OES) and inductively coupled plasma-mass spectrometry. The ICP-OES is a good technique for elemental analysis that offers high capacity for simultaneous determinations [9-11]. However, it should be also kept in mind that the presence of spectral interferences (undesirable signals interfering with the element signal) and non-spectral interferences (physical and chemical interferences, also called matrix interferences) may result in non- 
Table 1. Inductively coupled plasma-optical emission spectrometry operating conditions

\begin{tabular}{l|l}
\hline \multicolumn{1}{c|}{ Parameter } & \multicolumn{1}{c}{ Value } \\
\hline $\begin{array}{l}\text { Plasma observation configuration } \\
\text { Nebulizer type }\end{array}$ & $\begin{array}{l}\text { Radial } \\
\text { Perkin-Elmer cross } \\
\text { flow } \\
\text { Ryton double-pass } \\
\text { Scott-type } \\
\text { Spray chamber }\end{array}$ \\
$\begin{array}{l}\text { Sample uptake rate } \\
\text { Observation height }\end{array}$ & $15 \mathrm{~mm}$ above load coil \\
Torch injector internal diameter & $2.0 \mathrm{~mm}$ \\
Read time & $2 \mathrm{~s}$ \\
Measurement replicates & 5 \\
Plasma conditions & \\
$\quad$ generator of radiofrequency & $40 \mathrm{MHz}$ \\
radiofrequency incident power & $1300 \mathrm{~W}$ \\
plasma argón flow rate & $15 \mathrm{~L} / \mathrm{min}$ \\
auxiliary argon flow rate & $0.8 \mathrm{~L} / \mathrm{min}$ \\
nebulizer argon flow rate & $0.8 \mathrm{~L} / \mathrm{min}$ \\
\hline
\end{tabular}

correct analytical determinations. Therefore, in order to eliminate or control the negative effects of these interferences, it is necessary to use an optimized and validated ICP-OES method which permits to obtain quantification of elements with the accuracy and precision required.

The aim of the present study was to optimize and validate an ICP-OES method to determine the essential elements $\mathrm{Ca}, \mathrm{K}, \mathrm{Mg}, \mathrm{Na}$ and $\mathrm{P}$ in fish, since no information is available about the validation of ICP-OES to be used in the quantification of minerals in this biological material. Furthermore, the validated method was applied to determine the concentration of macro bioelements in both the muscle and the skin of farmed rainbow trout (Oncorhynchus mykiss).

\section{EXPERIMENTAL}

Instrumentation and reagents. Optima $3300 \mathrm{DV}$ inductively coupled plasma optical emission spectrometer (Perkin-Elmer, Palo Alto, CA, USA) was used for analytical determinations. Instrument configuration and general operating conditions are summarized in Table 1. A freeze-dry system (Liolabor 3 L-853264, Telstar S.A., Tarrasa, Spain) was employed for drying the muscle and skin samples from rainbow trout fillets. A high-pressure laboratory microwave oven (Millestone Ethos-1600 Microwave Labstation, Sorisole, Italy) programmable for time and microwave power (until $900 \mathrm{~W}$ ) was used for digestion of samples. A Fritsch-Pulverisette mill (Idar-Oberstein, Ger- many) was used to pulverize the freeze-dried muscle and skin rainbow trout samples.

High-purity Milli-Q water with a resistivity of 18.2 $\mathrm{M} \Omega \mathrm{cm}$ was obtained from a Milli-Q purification device (Millipore Co., Bedford, MA, USA) and employed in the preparation of samples and standard solutions, as well as for final rinsing of the glassware and plastic material. Nitric acid $65 \%$ and hydrogen peroxide $30 \%(\mathrm{w} / \mathrm{v})$ (both from Merck Millipore, Darmstadt, Germany) were used for sample digestion. Standard solutions were prepared by appropriate dilution of $10000 \mu \mathrm{g} / \mathrm{mL}$ of $\mathrm{Ca}, \mathrm{K}, \mathrm{Na}$ and $\mathrm{P}$ or $1000 \mu \mathrm{g} / \mathrm{mL}$ of $\mathrm{Mg}$ of Plasma CAL.SCP Science stock solutions (SCP Science Corporate, Quebec, Canada). All laboratory material employed in the preparation of samples and standard solutions was previously soaked in a nitric acid-water mixture $(1: 9, \mathrm{v} / \mathrm{v})$, washed with ultra-pure water and dried at room temperature.

Samples. The Certified Reference Material (CRM) coded as NIST SRM-1946 and available from the National Institute of Standards and Technology was used. This CRM is a frozen fish tissue homogenate from lake trout Salvelinus namaycush namaycush collected from Lake Superior (US/Canada) and used to evaluate analytical methods for the determination of polychlorinated pesticides, fatty acids or mineral elements in fish tissue and similar matrices.

Rainbow trouts for the current study were delivered by Piscifactorías Andaluzas (Loja, Granada, Spain). Fish was packaged individually in plastic bags and then transported on ice to our laboratory. On arrival at the laboratory, a total of 9 fish, with a mean weight of $223 \pm 26 \mathrm{~g}$, were filleted, and the skin was removed. The samples of muscle and skin were cut into small pieces, freeze-dried at $-40^{\circ} \mathrm{C}$ and pulverized in a mill. Each lot of muscle and skin samples was separately pooled, homogenized and stored in air-tight containers at $-25^{\circ} \mathrm{C}$. Four samples of the muscle and skin were analyzed.

Microwave-assisted acid digestion. Six replicate samples of the CRM were subjected to a microwaveassisted acid digestion. A portion of ca. $1 \mathrm{~g}$ from each sample was weighed and put carefully into a highpressure Teflon PFA digestion vessel (Milestone Srl., Sorisole, Italy). Then, $7 \mathrm{~mL}$ of a $\mathrm{HNO}_{3} / \mathrm{H}_{2} \mathrm{O}$ mixture $(3: 2, \mathrm{v} / \mathrm{v})$ and $1 \mathrm{~mL}$ of $\mathrm{H}_{2} \mathrm{O}_{2}$ were added. The vessels were tightly capped, shaken and placed into a microwave oven to be digested under the operating conditions that appear in Table 2. After digestion, the vessels were allowed to cool to room temperature, and the digested samples were quantitatively transferred into volumetric flasks and made up to $50 \mathrm{~mL}$ with ultrapure water. Another set of more diluted digestion samples was prepared in order to test accuracy and precision of the optimized method at two different concentrations of CRM. For which, a volume of $6.5 \mathrm{~mL}$ from each of the first digested solutions were diluted up to $10 \mathrm{~mL}$ with a $7 \mathrm{~mL}$ of a $\mathrm{HNO}_{3}-\mathrm{H}_{2} \mathrm{O}$ 
mixture $(3: 2, v / v), \mathrm{H}_{2} \mathrm{O}_{2}$ and ultrapure $\mathrm{H}_{2} \mathrm{O}$ in the adequate ratio $(7: 1, \mathrm{v} / \mathrm{v})$ to keep the same proportion of $\mathrm{HNO}_{3}$ and $\mathrm{H}_{2} \mathrm{O}_{2}$ in all digested solutions. A set of digestion reagent blanks was also prepared and subjected to the same microwave acid procedure and dilution conditions as the CRM samples. Similarly, rainbow trout samples (muscle and skin samples) were also subjected to microwave-assisted acid digestion. Because of the high major element concentration in the muscle and skin than in the CRM, the volume of $\mathrm{HNO}_{3}-\mathrm{H}_{2} \mathrm{O}$ mixture $(3: 2, \mathrm{v} / \mathrm{v})$ and $\mathrm{H}_{2} \mathrm{O}_{2}$ were 14 and $2 \mathrm{~mL}$, respectively, and the digested solutions were diluted up to $100 \mathrm{~mL}$. Five replicate analyses for both the muscle and the skin samples were carried out.

Preparation of standards solutions and calibration. Five multielemental standards solutions were prepared by appropriate dilution of stock commercial monoelemental solutions in order to obtain calibration graphs for the determination of $\mathrm{Ca}, \mathrm{K}, \mathrm{Mg}, \mathrm{Na}$ and $\mathrm{P}$. The concentrations of the five standard solutions were the following: $0,0.32,1.6,5.6,10.4$ and $16.0 \mu \mathrm{g} / \mathrm{mL}$ for $\mathrm{Ca} ; 0,20,50,100,150$ and $200 \mu \mathrm{g} / \mathrm{mL}$ for $\mathrm{K} ; 0,1,5$, 10,15 and $20 \mu \mathrm{g} / \mathrm{mL}$ for $\mathrm{Mg} ; 0,1,5,10,20$ and $30 \mu \mathrm{g} / \mathrm{mL}$ for $\mathrm{Na} ; 0,20,50,80,110$ and $150 \mu \mathrm{g} / \mathrm{mL}$ for P. All standard solutions were prepared by transferring the appropriate amount of stock commercial solution into a $50 \mathrm{~mL}$ volumetric flask and adding $7 \mathrm{~mL}$ of $\mathrm{HNO}_{3}-\mathrm{H}_{2} \mathrm{O}$ mixture $(3: 2, \mathrm{v} / \mathrm{v})$ and $1 \mathrm{~mL}$ of $\mathrm{H}_{2} \mathrm{O}_{2}$, the final volume being made with ultrapure water.

Validation parameters. The method based on ICPOES to determine major elements in fish was optimized and validate using a selected CRM and according to the rules and recommendations of the International Conference on Harmonisation [12] and the Eurachem Guidelines [13]. The process parameters calculated were the following: linearity, precision, accuracy, and limits of detection and quantification.

Linearity was evaluated by the correlation coefficient of standard calibration graph with the criterion that the coefficient $r$ should be $\geq 0.995$ [13]. As detailed above, each calibration graph included a blank and five multielemental solutions with increasing concentration of the tested elements. The mineral elements were measured three times in each solution.

Precision was assessed in terms of intra-day precision (repeatability) and inter-day precision (reproducibility) and expressed in both cases as percentage of the coefficient of variation (relative standard deviation, \%).

Repeatability of the over-all procedure was determined by analyzing twelve digested CRM samples (two sets of six replicates, each set containing a different concentration of CRM as described above) in five separate runs on the same day. Reproducibility was calculated on the same way that repeatability with the only difference that the digested CRM samples were analyzed on three different days.
Table 2. Microwave-assisted digestión conditions

\begin{tabular}{c|c|c|l}
\hline Stage & Power, W & $\begin{array}{c}\text { Total time, } \\
\text { min }\end{array}$ & Temperature, ${ }^{\circ} \mathrm{C}$ \\
\hline 1 & 700 & 3 & Until 100 \\
2 & 700 & 10 & 100 to 165 \\
3 & 700 & 5 & 165 to 190 \\
4 & 700 & 15 & 190 \\
\hline
\end{tabular}

Accuracy was expressed as percentage recovery comparing the measure value of each major element with the corresponding accepted certified value in CRM. To test accuracy of the optimized method, the obtained analytical data for intra-assay precision evaluation were used for calculating the recoveries $(\%)$ of $\mathrm{Ca}, \mathrm{K}, \mathrm{Mg}, \mathrm{Na}$ and $\mathrm{P}$.

Detection (LOD) and quantification (LOQ) limits of the method were calculated on the basis of 3SD and $10 \mathrm{SD}$, respectively, for ten replicate measurements using the following equations $[14,15]$ :

$$
\mathrm{LOD}=3 \mathrm{SD}_{\mathrm{b}} / b \text { and } \mathrm{LOQ}=10 \mathrm{SD}_{\mathrm{b}} / b \text {, }
$$

where $\mathrm{SD}_{\mathrm{b}}$ is the standard deviation of the measurements of ten digested reagent blank subjected to acid digestion and $b$ is the slope of the corresponding standard calibration graph.

Statistical analysis. Results were expressed as mean \pm standard deviation. All statistical, graphical, processing and tabulating procedures were performed using the Statgraphics Plus 5.1 software package (Manugistics Inc., Rockville, MD, USA). Differences were considered significant at $p<0.05$.

\section{RESULTS AND DISCUSSION}

Selection of emission spectral lines. Several analytical lines for $\mathrm{Ca}, \mathrm{Mg}$ and $\mathrm{P}$ determination were examined and the best one for each elements was selected. This selection was based on the relationship of signal intensity to element concentration and on the absence of spectral interferences. For $\mathrm{K}$ and $\mathrm{Na}$ determination, pre-selected lines by the ICP-OES instrument were used. The evaluated and selected spectral lines appear summarized in Table 3.

Validation of the method. Linearity of calibration graph. Intensity of emission line varied linearly with element concentration throughout the range used. As shown in Table 4, the coefficients of correlation for the five calibration graphs were higher than 0.9999, which indicated a very good linear relationship according to the linearity acceptance criterion of $r>0.995$ suggested by the Eurachem Guidelines [13]. This was also supported by the results obtained from the linearity tests based on the values of response factor and calibration graph slope. As can be seen in the Table 4, the relative standard deviation of response factor (ratio between signal intensity and element concentration) 
Table 3. Spectral lines evaluated and selected for the determination of major elements in rainbow trout

\begin{tabular}{c|c}
\hline Element & Detection wavelengths, $\mathrm{nm}$ \\
\hline $\mathrm{Ca}$ & 317.933 \\
& 315.887 \\
& $396.847^{\mathrm{a}}$ \\
$\mathrm{K}$ & 422.673 \\
$\mathrm{Mg}$ & $766.490^{\mathrm{a}}$ \\
& $285.213^{\mathrm{a}}$ \\
& 279.077 \\
& 280.271 \\
$\mathrm{Na}$ & 279.553 \\
$\mathrm{P}$ & $589.592^{\mathrm{a}}$ \\
& $213.617^{\mathrm{a}}$ \\
& 214.914 \\
\hline
\end{tabular}

${ }^{\mathrm{a} S e l e c t e d ~ w a v e l e n g t h}$.

ranged from $0.37 \%$ for $\mathrm{Na}$ to $2 \%$ for $\mathrm{K}$, which is markedly lower than the $<5 \%$ of the acceptance criterion [16]. For calibration graph slope, the RSDs ranged from $0.06 \%$ for $\mathrm{Ca}$ to $0.63 \%$ for $\mathrm{K}$, which is also lower than the recommended acceptance criterion $(<2)[13]$.

Precision and accuracy. The results on precision and accuracy are summarized in Tables 5 and 6. Precision of the method was evaluated in terms of repeatability (intra-day assay) and reproducibility (inter-day assay), results being expressed by percentage relative standard deviation (RSD, \%). Based on the data from Tables 5, 6, it can be seen that the RSD found for repeatability of the over-all procedure were consistent with the corresponding RSDs found for reproducibility. Thus, RSD values for repeatability ranged from 1.2 to $6.5 \%$ and those for reproducibility ranged from 1.0 to $4.9 \%$. For both types of assays, the RSD was minimum for $\mathrm{K}(1.2$ to $1.6 \%)$ and maximum for $\mathrm{Ca}$ (3.5 to $6.5 \%)$. These results evidenced that a good precision was achieved for all major element determinations. According to these results, all measured values fulfilled the precision requirements set by the International Conference of Harmonisation of Technical Requirements for Registration of Pharmaceuticals for
Human Use [12]. These requirements are: both the mean percentage difference and the mean RSD of measured values should not exceed $\pm 10 \%$ of the certified values for CRM and, at least, $75 \%$ of measured concentrations had to be within $\pm 15 \%$ of certified concentrations. In addition, no more than one of six samples within a given concentration could exceed $\pm 10 \%$ of the corresponding certified concentration. As in the case of accuracy assay, both the repeatability and the reproducibility values were within the acceptance criterion mentioned above [12].

With respect to accuracy, a good agreement between measured and certified values in the CRM was achieved for the five elements studied. On the whole, data from the intra and inter-day assays taken together revealed that the mean percentage differences between measured and certified values were lower than $4.9 \%$ for $\mathrm{K}, \mathrm{Mg}$, $\mathrm{Na}$ and $\mathrm{P}$ and $9.7 \%$ for $\mathrm{Ca}$. Percentage difference values translated to relative recoveries $(\%)$, for each major element were the following: $\mathrm{Ca}, 102.7-109.7$; K, 101.6-102.8; Mg, 103.3-104.9; $\mathrm{Na}, 97.83-98.69$ and $\mathrm{P}, 99.79-103.05$. Our results also showed that the accuracy values for major elements were rather similar for the two sets of digested samples with high or low concentration. These results evidenced that a good accuracy was achieved for all major element determinations. As in the case of precision assays, accuracy values were within the above mentioned acceptance criterion [12].

Limits of detection and quantification. The LOD is defined as the lowest concentration of analyte which one can decide whether an element is present in a sample. The LOQ is defined as the lowest concentration of an analyte that can be determined with acceptable accuracy and precision [14, 15, 17]. Table 7 contains the experimental data obtained for these limits in the present work. As shown in this Table, the lowest LOD $(1.2 \mathrm{ng} / \mathrm{mL})$ and the lowest LOQ $(4.0 \mathrm{ng} / \mathrm{mL})$ were found for both $\mathrm{Ca}$ and $\mathrm{Mg}$, whereas the highest ones (61 and $203 \mathrm{ng} / \mathrm{mL}$, respectively) were found for $P$. In all cases the LOD and LOQ were considered satisfactory indicating that the microwave acid-digestion treatment provided a clean sample preparation.

Major elements in rainbow trout. Results on the mineral content of $\mathrm{Ca}, \mathrm{K}, \mathrm{Mg}, \mathrm{Na}$ and $\mathrm{P}$ in the two edible parts (muscle and skin) of farmed rainbow trout

Table 4. Standard calibration graph, assay of linearity for major elements ${ }^{\mathrm{a}}$

\begin{tabular}{c|c|c|c|r|c}
\hline Element & Slope & RSD, $\%$ & Intercept & Response factor & \multicolumn{1}{c}{ RSD, $\%$} \\
\hline $\mathrm{Ca}$ & $3.45 \times 10^{5} \pm 200$ & 0.06 & $+3710 \pm 1800$ & $3.463 \times 10^{5} \pm 1.4 \times 10^{3}$ & 0.41 \\
$\mathrm{~K}$ & $1337 \pm 8$ & 0.63 & $-610 \pm 950$ & $1315 \pm 32$ & 2.4 \\
$\mathrm{Mg}$ & $2.975 \times 10^{4} \pm 40$ & 0.14 & $+222 \pm 472$ & $2.975 \times 10^{4} \pm 150$ & 0.52 \\
$\mathrm{Na}$ & $6011 \pm 25$ & 0.42 & $+363 \pm 389$ & $6020 \pm 22$ & 0.37 \\
$\mathrm{P}$ & $191 \pm 1$ & 0.45 & $-46 \pm 74$ & $190 \pm 1$ & 0.53 \\
\hline
\end{tabular}

${ }^{\mathrm{a}}$ The correlation coefficient was 0.9999 for all elements. Results are expressed as mean \pm standard deviation $(n=6)$ 
Table 5. Analysis of Certified Reference Material NIST 1946: intra-day accuracy and precision of the optimized method

\begin{tabular}{|c|c|c|c|c|c|c|c|c|}
\hline \multirow{3}{*}{ Element } & \multicolumn{4}{|c|}{ Low concentration $^{a}$} & \multicolumn{4}{|c|}{ High concentration $^{a}$} \\
\hline & \multicolumn{3}{|c|}{ accuracy } & \multirow{2}{*}{$\begin{array}{c}\text { precision } \\
(\mathrm{RSD}, \%)\end{array}$} & \multicolumn{3}{|c|}{ accuracy } & \multirow{2}{*}{$\begin{array}{l}\text { precision } \\
(\mathrm{RSD}, \%)\end{array}$} \\
\hline & $\begin{array}{c}\text { certified, } \\
\mu \mathrm{g} / \mathrm{g}\end{array}$ & found, $\mu \mathrm{g} / \mathrm{g}$ & difference, $\%$ & & $\begin{array}{c}\text { certified, } \\
\mu \mathrm{g} / \mathrm{g}\end{array}$ & found, $\mu \mathrm{g} / \mathrm{g}$ & difference, $\%$ & \\
\hline $\mathrm{Ca}$ & $38 \pm 1$ & $39 \pm 3$ & 2.7 & 6.5 & $59 \pm 2$ & $61 \pm 4$ & 3.8 & 6.33 \\
\hline $\mathrm{K}$ & $2165 \pm 117$ & $2215 \pm 35$ & 2.3 & 1.6 & $3330 \pm 180$ & $3423 \pm 42$ & 2.8 & 1.22 \\
\hline $\mathrm{Mg}$ & $147 \pm 12$ & $153 \pm 3$ & 3.9 & 1.9 & $226 \pm 19$ & $236 \pm 4$ & 4.2 & 1.56 \\
\hline $\mathrm{Na}$ & $298 \pm 16$ & $292 \pm 7$ & 2.0 & 2.6 & $458 \pm 25$ & $452 \pm 10$ & 1.3 & 2.11 \\
\hline $\mathrm{P}$ & $1288 \pm 26$ & $1303 \pm 40$ & 1.2 & 3.1 & $1980 \pm 40$ & $2041 \pm 82$ & 3.1 & 4.00 \\
\hline
\end{tabular}

${ }^{a}$ Values are means of six replicates \pm standard deviation.

Table 6. Analysis of Certified Reference Material NIST 1946: inter-day accuracy and precision of the optimized method

\begin{tabular}{|c|c|c|c|c|c|c|c|c|}
\hline \multirow{3}{*}{ Element } & \multicolumn{4}{|c|}{ Low concentration ${ }^{\mathrm{a}}$} & \multicolumn{4}{|c|}{ High concentration $^{\mathrm{a}}$} \\
\hline & \multicolumn{3}{|c|}{ accuracy } & \multirow{2}{*}{$\begin{array}{l}\text { precision } \\
\text { (RSD, \%) }\end{array}$} & \multicolumn{3}{|c|}{ accuracy } & \multirow{2}{*}{$\begin{array}{l}\text { precision } \\
\text { (RSD, \%) }\end{array}$} \\
\hline & certified, $\mu \mathrm{g} / \mathrm{g}$ & found, $\mu \mathrm{g} / \mathrm{g}$ & difference, $\%$ & & certified, $\mu \mathrm{g} / \mathrm{g}$ & found, $\mu \mathrm{g} / \mathrm{g}$ & difference, $\%$ & \\
\hline $\mathrm{Ca}$ & $38 \pm 1$ & $41 \pm 1.4$ & 5.8 & 3.4 & $59 \pm 2$ & $65 \pm 3$ & 9.7 & 4.9 \\
\hline $\mathrm{K}$ & $2165 \pm 117$ & $2207 \pm 34$ & 2.0 & 1.6 & $3330 \pm 180$ & $3385 \pm 39$ & 1.6 & 1.2 \\
\hline $\mathrm{Mg}$ & $147 \pm 12$ & $154 \pm 4$ & 4.9 & 2.6 & $226 \pm 19$ & $234 \pm 3$ & 3.3 & 1.2 \\
\hline $\mathrm{Na}$ & $298 \pm 16$ & $293 \pm 5$ & 1.6 & 1.6 & $458 \pm 25$ & $448 \pm 4$ & 2.2 & 1.0 \\
\hline $\mathbf{P}$ & $1288 \pm 26$ & $1286 \pm 27$ & 0.2 & 2.5 & $1980 \pm 40$ & $2001 \pm 50$ & 1.0 & 2.5 \\
\hline
\end{tabular}

${ }^{a}$ Values are means of six replicates \pm standard deviation.

fillet, as determined by the proposed ICP-OES method, are shown in Table 8. The concentrations of these essential elements differed between the two edible parts of the fillet. Among the five elements analyzed, $\mathrm{K}$ followed by $\mathrm{P}$ in the muscle and both $\mathrm{Ca}$ and $\mathrm{P}$ in the skin were the predominant minerals. The concentrations of these five elements differed between the edible parts of the fillet. The mean Ca content in the skin was $c a$. thirteen times higher than in the muscle, whereas the mean $\mathrm{K}$ and $\mathrm{Mg}$ contents were $\mathrm{c} a$. three and two times higher, respectively, in the muscle than in the skin. These observations agree with previous results $[4,18]$. In contrast with these findings, other published data showed a higher level of $\mathrm{Ca}$ in the muscle than in the skin of this fish [19]. Smaller differences, but also statistically significant $(P<0.001)$ were detected between the muscle and the skin for $\mathrm{Na}$ and $\mathrm{P}$ contents.

Additionally, it should be also mentioned the low $\mathrm{Na} / \mathrm{K}$ ratio observed in both the muscle and the skin of the farmed rainbow trout fillet $(0.12$ and 0.28 , respectively). This finding has dietetic significance because low $\mathrm{Na}$ or $\mathrm{K}$ intake has been associated to a reduction in blood pressure in humans [20, 21]. Regarding this topic, other recent studies have shown that the $\mathrm{Na} / \mathrm{K}$ ratio may have a larger beneficial effect

Table 7. Limits of detection and quantification $(\mathrm{ng} / \mathrm{mL})$ of the method

\begin{tabular}{c|c|c|c|c}
\hline Element & $\sigma_{\mathrm{b}}$ & Slope & LOD & LOQ \\
\hline $\mathrm{Ca}$ & $1.4 \times 10^{4}$ & $3.45 \times 10^{5}$ & 1.2 & 4 \\
$\mathrm{~K}$ & 17 & $1.34 \times 10^{3}$ & 37 & 125 \\
$\mathrm{Mg}$ & 12 & 29753 & 1.2 & 4 \\
$\mathrm{Na}$ & 37 & 6011 & 19 & 62 \\
$\mathrm{P}$ & 3.9 & 191 & 61 & 203 \\
\hline
\end{tabular}

$\sigma_{\mathrm{b}}$ : standard deviation of the blank, calculated from 10 measurements of the intensity of the reactive blank; LOD $=3 \sigma_{\mathrm{b}} /$ slope; $\mathrm{LOQ}=10 \sigma_{\mathrm{b}} /$ slope 
Table 8. Major elements in the muscle and skin $(\mathrm{mg} / \mathrm{kg} \text { dry matter })^{\mathrm{a}}$ of farmed rainbow trout determined by the proposed optimized ICP-OES method

\begin{tabular}{c|c|c|c|c|c}
\hline Element & Muscle & RSD, $\%$ & Skin & RSD, $\%$ & SE \\
\hline $\mathrm{Ca}$ & $916 \pm 10$ & 1.1 & $11950 \pm 72$ & 0.6 & 22.87 \\
$\mathrm{~K}$ & $17900 \pm 188$ & 1.1 & $5355 \pm 78$ & 1.4 & 64.65 \\
$\mathrm{Mg}$ & $1147 \pm 12$ & 1.0 & $552 \pm 6$ & 1.1 & 4.22 \\
$\mathrm{Na}$ & $2187 \pm 24$ & 1.1 & $1480 \pm 10$ & 0.7 & 8.11 \\
$\mathrm{P}$ & $10913 \pm 63$ & 0.6 & $11882 \pm 185$ & 1.6 & 61.76 \\
\hline
\end{tabular}

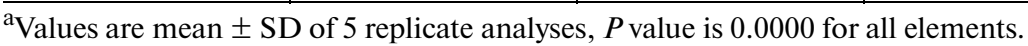

on blood pressure that the effect either $\mathrm{Na}$ or $\mathrm{K}$ alone [22-24].

\section{CONCLUSIONS}

An optimized and validated ICP-OES method was developed to determine major elements $(\mathrm{Ca}, \mathrm{K}, \mathrm{Mg}$, $\mathrm{Na}$ and $\mathrm{P}$ ) in rainbow trout tissues (muscle and skin). The method was validated in terms of linearity, sensitivity, accuracy, precision, and detection and quantification limits using a Certified Reference Material, coded as NIST SRM1946 (frozen fish tissue homogenate prepared from lake trout). Assisted micro-wave acid digestion and further determination with ICPOES led to very good accuracy and precision results for the five elements determined. Moreover, the optimized and validated method fulfills the requirements necessary to determine major elements in many food products of animal and vegetable origin.

\section{ACKNOWLEDGMENTS}

The authors thank Dibaq Diproteg S.A. and the staff of Piscifactorias Andaluzas for their cooperation.

\section{REFERENCES}

1. MAGRAMA, Ministerio de Agricultura, Alimentación y Medio Ambiente. Producción de Acuicultura. Madrid, Spain, 2012.

2. Hunter, B.J. and Roberts, D.C.K., Nutr. Res., 2000, vol. 20, p. 1047.

3. Burger, J. and Gochfeld, M., Environ. Res., 2009, vol. 109, p. 343.

4. Rebolé, A., Velasco, S., Rodríguez, M.L., Treviño, J., Alzueta, C., Tejedor, J.L., and Ortiz, L.T., Food Chem., 2015, vol. 174, p. 614.

5. Mayneris-Perxachs, J., Bondia-Pons, I., SerraMajem, L., and Castellote, A.I., Food Chem., 2010, vol. 119, p. 54.

6. Lal, S.P., in Fish Nutrition, Halver, J.E., Ed., San Diego, CA: Academic, 1989, p. 220.

7. Lal, S.P., in Fish and Fishery Products: Composition, Nutritive Properties and Stability, Ruiter, A., Ed., Wallingford, CN: CAB Int., 1995, p. 187.

8. Liang, Y. and Wong, M.H., Arch. Environ. Contam. Toxicol., 2000, vol. 39, p. 506.
9. Mermet, J.M., J. Anal. Atom. Spectrom., 2005, vol. 20 , p. 11.

10. Moreda-Piñeiro, J., Alonso-Rodríguez, E., LópezMaia, P., Muñategui-Lorenzo, S., PradaRodríguez, D., Moreda-Piñeiro, A., and BermejoBarrera, P., Anal. Chim. Acta, 2007, vol. 598, p. 95.

11. Larrea-Marin, M.T., Pomares-Afonso, M.S., GómezJuaristi, M., Sánchez-Muniz, F.J., and Ródenas de la Rocha, S., J. Food Compos. Anal., 2010, vol. 23, p. 814.

12. International Conference on Harmonization of Technical Requirements for Registration of Pharmaceuticals for Human Use, 1996.

13. A Laboratory Guide to Method Validation and Related Topics, Eurachem Working Group, 1998. https://www. eurachem.org/index.php/publications/guides/mv.

14. International Union of Pure and Applied Chemistry: Compendium of Chemical Terminology, Cambridge, UK, 1997, 2nd ed.

15. Thomsen, P., Schatzlein, D., and Mercuro, D., Spectroscopy, 2003, vol. 18, p. 112.

16. Castro, M., Gascón, S., Pujol, M., Sans, J.M., and Vicente, L., Validación de métodos analíticos. Asociación Española de Farmacéuticos de la Industria, Monografia AEFI, Sección Catalana, Comisión de Normas de Buena Fabricación y Control de la Calidad, Hewlett Packard, 1989.

17. Veeramachaneni, M. and Jayavarapu, K.R., J. $A d v$. Pharm. Tech. Res., 2013, vol. 3, p. 516.

18. Shearer, K.D., Can. J. Fish. Aquat. Sci., 1984, vol. 41, p. 1592.

19. Brucka-Jastrzębska, E., Kawczuga, D., Rajkowska, M., and Protasowicki, M., J. Elem., 2009, vol. 14, no. 3, p. 437.

20. Aburto, N.J., Ziolkovska, A., Hooper, L., Elliott, P., Cappuccio, F.P., and Meerpohl, J.J., Br. Med. J., 2013, vol. 346.

21. He, F.J., Li, J., and Macgregor, G.A., Br. Med. J., 2013, vol. 346.

22. Intersalt Cooperative Research Group, Br. Med. J., 1988, vol. 297, p. 319.

23. Sacks, F.M., Svetkey, L.P., Vollmer, W.M., Appel, L.J., Bray, G.A., Harsha, D., Obarzanek, E., Conlin, P.R., Miller, E.R., Simons-Morton, D.G., Karanja, N., and Lin, P.H., New Engl. J. Med., 2001, vol. 344 , p. 3.

24. Du, S., Batis, C., Wang, H., Zhang, B., Zhang, J., and Popkin, B.M., Am. J. Clin. Nutr., 2014, vol. 99, p. 334. 